\title{
PROCEED WITH CAUTION: LAW REFORM, JUDICIAL REVIEW AND THE JUDICATURE MODERNISATION BILL
}

\author{
Morgan Watkins*
}

The Judicature Modernisation Bill 2013 re-enacts the operative provisions of the Judicature Amendment Act 1972. This article analyses the re-enacted provisions, concluding that the reform will be largely successful relative to a goal of "non-substantive reform". However, this article argues that there were significant defects in the legislative process leading to reform, especially in terms of parliamentary scrutiny of judicial review. In a context of a fused executive-legislative branch of government, it is inappropriate to legislate for judicial review without adequate consideration of the effects on judicial review powers and processes. This article argues that judicial review procedure should not be contained in statute in order to prevent executive control of the statutory review procedure.

Quality can be an elusive idea but it does not, like beauty, lie in the eye of the beholder. ${ }^{1}$

\section{INTRODUCTION}

The general idea of New Zealand's constitution is that Parliament has full power to make any law that it decides it is necessary to make. ${ }^{2}$ This article's central thesis is that, even if this is true, the elected legislature should not exercise that power to legislate for judicial review. The main reason for this is simple: the fusion of executive and legislature is so advanced in New Zealand that politically ceding the power to regulate judicial review to Parliament is to cede it also to the executive. That the

* Submitted as part of the LLB(Hons) programme at Victoria University of Wellington. I am grateful to Dr Dean Knight for his patient support and advice in the writing of this article. I am indebted to him.

1 Geoffrey Palmer "Law Making in New Zealand: Is There A Better Way?" (2014) 22 Wai L Rev 1 at 3.

2 Constitution Act 1986, s 15(1); Jackson v Attorney-General [2005] UKHL 56 at [102] per Lord Steyn; and compare generally Sian Elias "Sovereignty in the 21st Century: Another Spin on the Merry-go-round" (2003) 14 PLR 148 at 150. 
executive could effectively direct how a judge should determine the legality of its actions is undesirable in a system where the rule of law is the "guiding light of constitutional propriety". ${ }^{3}$

The closely related question of whose role it is to administer and define judicial review in New Zealand is of substantial significance. I will explain why I am deeply sceptical of parliamentary interference in judicial review with close reference to the omnibus Judicature Modernisation Bill 2013. The Bill is an excellent example of a legislature wasting an opportunity to make good on known issues. It is not enough to cite the Bill's moderate successes in the unambitious goal of non-substantive reform as justification for that lapse. There has been, so far, highly inadequate legislative scrutiny in the process of passing the Judicature Modernisation Bill. This raises questions of whether Parliament has enough control over the content of legislation, such that the legislation it passes can be plausibly seen as passed by Parliament at all. ${ }^{4}$ My criticisms are rooted in a commitment to the rule of law, which I and others believe to be underappreciated in New Zealand. ${ }^{5}$ As such, the Judicature Modernisation Bill is a timely example of why Parliament needs to tread carefully when legislating for constitutional essentials.

I will go on to discuss the nature of judicial review as a common law power. Because judicial review's origins lie in the inherent jurisdiction of the High Court, there is a basic tension with any view that argues Parliament is lawfully sovereign. It is not enough to sidestep this conflict as resoluble with a deft touch of statutory interpretation. ${ }^{6}$ Even if Parliament was a perfect legislator, it makes little sense to speak of a legislative intent to enable judicial review. For the most part, Parliament has not turned its mind to judicial review process and arguments for implied intention mask the historical nature of review as a tool fashioned by courts. The implication of these insights for statutory amendments to review process is that Parliament is, essentially, meddling. Accordingly, Parliament needs to rethink the role it plays in establishing judicial review process in order to better protect the power of review. Whether that role is the same but subject to more cautious processes, or a refusal to use legislative power, is perhaps not too important. Either would be a better protection for judicial review than undue interference.

This article comes from a generally instrumental perspective. In my view, the main value of public law is its role as moderator of public power in a broad sense. But public power depends on its

3 Matthew SR Palmer "Assessing the Strength of the Rule of Law in New Zealand" (paper presented to the New Zealand Centre for Public Law "Unearthing New Zealand's Constitutional Traditions" Conference, Wellington, August 2013) at 1. For a good working definition of the rule of law, see Matthew SR Palmer "New Zealand Constitutional Culture" (2007) 22 NZULR 565 at 587.

4 Palmer, above n 1, at 21.

5 See for example Palmer "New Zealand Constitutional Culture", above n 3, at 589; and Claudia Geiringer "Inaugural Lecture: Mr Bulwark and the Protection of Human Rights" (2014) 45 VUWLR 367.

6 TRS Allan Constitutional Justice: A Liberal Theory of the Rule of Law (Oxford University Press, Oxford, 2001) at 210 . 
perceived legitimacy, which in turn depends on exercised authority not exceeding proper bounds. Therefore, in making my argument I am conscious the judiciary cannot overreach if it is to retain its respect. ${ }^{7}$ However, the same must be said of Parliament. The first principle of our constitution is not that Parliament is sovereign, it is that "no principle should be over-stressed or pushed to its limits". 8 That insight is part of what animates the principles of comity and it is not a one-way street. Parliament may be New Zealand's supreme law-making power, but that is different from saying it is the only one that must be respected. Current parliamentary attitudes to judicial review err too closely to the latter view.

\section{BACKGROUND TO THE JUDICATURE MODERNISATION $B I L L$}

The Judicature Modernisation Bill 2013 entered the parliamentary agenda when it was introduced to the House on 27 November $2013 .{ }^{9}$ The Bill had been a part of an intensive study at the Law Commission since the 2010 request of then-Minister of Justice Simon Power. The purpose of the review was quite straightforward: modernisation and reorganisation of the Judicature Act 1908, not reform as such. Substantive change or revisiting of "major matters of policy" in the law of the courts and civil procedure was explicitly not within the terms of reference. ${ }^{10}$

Rather than addressing judicial review, most of the Judicature Modernisation Bill concerns enactments required following its simultaneous repeal of the Judicature Act 1908. These enactments notably include the establishment of a unitary District Court, increased provision for the online publishing of judgments and the potential for a commercial list in the High Court. By contrast, the Law Commission's terms of reference only minimally touch on judicial review. ${ }^{11}$ The District Court structure is irrelevant to judicial review. Online publishing of judgments, a commercial list in the High Court and a programme of modernising language are at best only tangentially relevant to judicial review. Therefore, the Judicature Modernisation Bill has rather little to do with judicial review overall.

The only reason judicial review came up for study at all by the Commission was an unhappy legislative abnormality. Statutory rules for judicial review procedure are contained in the Judicature Amendment Act 1972 which peculiarly stands apart from the principal 1908 Act while also being

7 GDS Taylor Judicial Review: a New Zealand perspective (Butterworths, Wellington, 1991) at [1.01].

8 Ferdinand Mount The British Constitution Now: Recovery or Decline? (William Heinemann, London, 1992) at 81, as cited in Elias, above n 2, at 4 .

9 The Bill can be found online, along with all submissions and evidence, at the New Zealand Parliament website. See House of Representatives "Judicature Modernisation Bill" (18 February 2015) <www.parliament.nz>; and see generally Judicature Modernisation Bill 2013 (178), especially pt three.

10 Law Commission Review of the Judicature Act 1908: Towards a New Courts Act (NZLC R126, 2012), at iv.

11 At Appendix 1. 
read as part of it. ${ }^{12}$ Because the proposed reform of the courts includes a repeal of the 1908 Act, it would orphan the Judicature Amendment Act. ${ }^{13}$ The Commission was concerned that without reenactment it would cease to be a cogent legislative enactment. This shows, however, that the inclusion of judicial review in the Judicature Modernisation Bill is little more than a consequential amendment stemming from an unrelated legislative agenda.

The terms of reference for the Commission's review contained one initial suggestion that related to judicial review: a new "Civil Procedure Act". ${ }^{14}$ This would have been, presumably, a one-stop statute for matters of procedure including judicial review. That degree of codification was not preferred by the Commission, who opted for a new stand-alone "Judicial Review (Statutory Powers) Bill" instead. ${ }^{15}$ As it happens, this is more or less the path taken by the Government; the Judicature Modernisation Bill will split into a variety of Bills at the third reading stage, one of which will become the new Judicial Review Procedure Act. ${ }^{16}$ The text of the Act will comprise what is currently pt three of the Bill.

General consensus appears to be that the Bill presents a suitable opportunity to modernise the language of the Judicature Amendment Act. ${ }^{17}$ Changing the language of an enactment without changing its operation as law is always risky, but it appears to have generally succeeded in this case. At a minimum, it can be fairly described as the universal intention of all parties - nobody is attempting a back-door reform. Yet, worthy of note is the caveat deployed by the Commission that the Judicature Modernisation Bill generally is not a pure consolidation where the substantive law could be certified as not changing at all. ${ }^{18}$

\section{WHAT REFORM?}

I turn now to pt three of the Judicature Modernisation Bill and analyse some of the major points of contention in the statutory language. Although the substantive operation of the law as relates to judicial review procedure is not meant to change, the way it looks certainly will. There is one exception: rights of appeal against interlocutory orders are curtailed to an uncertain extent. This article focuses on major areas of debate to illustrate that general picture.

12 Judicature Amendment Act 1972, s 1

13 Law Commission, above n 10, at 8.

14 At Appendix 1, para (b).

15 At Appendix 3.

16 (18 February 2015) 703 NZPD 1725.

17 Law Commission, above n 10, at 4. See also Appendix 3.

18 At iv-v. 


\section{A Troubleshooting the Idea of "Non-Substantive Reform" Per Se}

To begin, cl 423 of the Bill explicitly provides an uncontroversial and well-settled purpose for the proposed stand-alone Act: ${ }^{19}$

\section{Purpose of this Part}

(1) The purpose of this Part is to re-enact Part 1 of the Judicature Amendment Act 1972, which sets out procedural provisions for the judicial review of-
(a) the exercise of a statutory power;
(b) the failure to exercise a statutory power; [and]
(c) the proposed or purported exercise of a statutory power.

(2) The reorganisation in this Part of those provisions, and the changes made to their style and language, are not intended to alter the interpretation or effect of those provisions as they appeared in the Judicature Amendment Act 1972.

As it appears here, cl 423 is a powerful statement of purpose that should correct any especially technical reading of the Judicature Modernisation Bill that may arise. It channels the essence of the Judicature Amendment Act as a mostly-procedural enactment. ${ }^{20}$ For the most part, only minor language changes have been made to it, to reflect modern drafting practice. Even where the language may seem expansively different, the effect in terms of substantive law change is likely to be construed quite narrowly to respect this purpose section. As such, it is a useful statutory aid.

The problem is that defining non-substantive reform is conceptually strained. It requires the law reformer to be self-contradictory, to intend to both do something new and achieve nothing new by the same action. Even if it is possible, as it seems it will be with the re-enactment of the Judicature Amendment Act, there is a constant pressure to check each provision rigidly to ensure there is no real way it can be misinterpreted. The burden on statutory language becomes even harsher than usual because there is always the background question of whether Parliament intended a given section to be a substantive reform despite the purpose clause. Such a general clause is unlikely to be determinative on its own. That is, the competing presumption that each language change is intended to have legal effect is not put aside, but modified. Because of this, clearly articulating the goals of the reform and also establishing the means of achieving it in a way which recognises that goal is sometimes prohibitively difficult. Even where it is done perfectly - and the Bill is far from perfect the issue of vagueness is unresolved. For this reason it is sometimes simply better to start afresh rather than re-enact the old law. ${ }^{21}$

19 Judicature Modernisation Bill (178-2), cl 423.

20 Taylor, above n 7, at [2.02]; and Law Commission, above n 10, at [2.1].

21 Palmer, above n 1, at 4. 
For example, what happens when the ordinary meaning of the new Act is at odds with the old interpretation? Statutory interpretation is always a matter of judicial construction. ${ }^{22}$ It is sometimes, in practice, open to a judge to undermine actual parliamentary intention in the interpretation of any offending section of the new Act, provided that is permitted by the text and can be justified on alternative grounds. ${ }^{23}$ That is doubly true when other important values are at stake. ${ }^{24}$ Premonition of future court rulings is not an exact science; for present purposes it is sufficient to note that an enterprising lawyer on the right facts may be able to abuse a loophole in this or similar purpose sections if they find a suitable problem in the statutory language. Importantly, that is a prospective vulnerability in a purpose clause constructed in the manner of cl 423 and a powerful reason for why they should be avoided in general.

Further, the purpose clause is limited to changes of language in the provisions that are in fact reenacted. That is, the language of provisions in the Judicature Modernisation Bill is not intended to alter the interpretation of those provisions as they appeared in the Judicature Amendment Act. But omission of a given clause is not comparable to a change in style or organisation of language: excluded sections fall outside the purpose section because they do not actually appear in the Part to which the purpose section refers. Thus, an omitted provision is not a reorganised provision in the Bill in other than a sparse legalistic sense. It is a stretch to claim the lack of statutory language in a Bill covered by a purpose clause like cl 423 , such as the omission of s $4(2 \mathrm{~A})$ 's proviso, ${ }^{25}$ can be read as having the same effect as the positive statutory language that it had in the old Act. In falling outside that purpose clause, each omitted section has the possibility, depending on its content, to change the substantive law. Not every omission of this kind will be intended or harmless.

Purpose clauses in the manner of $\mathrm{cl} 423$ will never be a complete solution to problems of statutory drafting. The overall result is that when done badly the effects of so-called non-substantive or technical reform can be too unclear to be workable, especially when reliant on these clauses. This is not merely about being technically correct. That a proviso is unnecessary or omitted provisions are

22 Allan, above n 6, at 210.

23 Interpretation Act 1999, s 5. See also Rv Pora [2001] 2 NZLR 37 (CA) per Elias CJ; and $R v$ Poumako [2000] 2 NZLR 695 (CA) at 702.

24 See for example judicial approaches to $\mathrm{s} 6$ of the Bill of Rights Act in Hansen $v R$ [2007] NZSC 58, [2007] 3 NZLR 1 at [13]-[18] per Elias CJ.

25 Section 4(2A) of the Judicature Amendment Act 1972 prohibits any enlargement or modification of the grounds of review that may come from explicitly permitting relief even where the decision maker is not bound to act judicially. Because the prohibition of enlargement or modification is omitted from the Judicature Modernisation Bill, its language cannot be said to be reorganised in this part of the Bill. Thus, it falls outside the scope of cl 423 and may amount to a change in the law through the removal of that statutory bar. As discussed below, the professional opinion is that this is not problematic law; however, this example does demonstrate another weakness in purpose clauses like cl 423. 
included elsewhere is rather beside the point. This incompleteness of coverage in the purpose clause demonstrates a defect in the Bill's law reform process per se.

\section{B Notable Changes in Drafting}

Provisions proclaiming the best of intentions cannot overcome defects in legislative drafting, which are more likely to occur the more often this method of reform is attempted. Something more is required from our legislators. For the most part, fortunately, there are few issues in the modernisation and redrafting of the Judicature Amendment Act as it relates to judicial review.

Because judicial review is intended to be an expeditious review of the exercise of public power, the courts' continued power of review is central. That power was bounded and given alternative form by the statutory procedure in s 4 of the Judicature Amendment Act. Although the section does not confer powers of review, its importance is demonstrated by the fact that most applications for judicial review are done through the Act's process. ${ }^{26}$ Section 4 provided for the possibility of relief that an applicant would be entitled to under proceedings in the nature of a writ of mandamus, prohibition, certiorari, or a declaration or injunction. ${ }^{27}$ It also provided that such remedies were discretionary, ${ }^{28}$ that one remedy was to have the decision maker reconsider the decision reviewed, ${ }^{29}$ and that in such cases the decision maker would have to consider such things as the court directed in coming to a new decision. ${ }^{30}$ Arguably, s 4 is the most important thing to get right in the Bill.

These provisions are mostly retained in cls $436-438$ of the Bill. Clause 436 deals primarily with availability of remedies. ${ }^{31}$ It preserves court power to set aside an unauthorised use of discretion. The rule in $\mathrm{s} 4(2 \mathrm{~A})$ that an absence of a duty to act judicially will not bar an application for review is retained. ${ }^{32}$ Omission of the proviso in s $4(2 \mathrm{~A})$ of the Judicature Amendment Act, that removal of this bar "shall not be construed as enlarging or modifying" the grounds for review, is not problematic. The Commission's view that it is difficult to construe the section as enlarging or modifying the grounds for review seems well-founded. ${ }^{33}$ Clause 437 effectively re-enacts subss 4(5)-(5C) as they relate to the direction of the decision maker subject to review proceedings. Clause 438 preserves the

26 Law Commission, above n 10, at [2.1]. See also Dean Knight "Privately Public" (2013) 24 PLR 108, for discussion of the view that the Judicature Amendment Act is a "source" of review jurisdiction.

27 Judicature Amendment Act 1972, s 4(1).

28 Section 4(2), (3) and (4).

29 Section $4(5)-(5 C)$.

30 Section 4(6).

31 Judicature Modernisation Bill 2013 (178-2), cl 436(1)-(2).

32 Judicature Modernisation Bill 2013 (178-2), cl 436(3).

33 Law Commission, above n 10, at [2.44]. 
discretionary nature of relief as it exists under the Judicature Amendment Act. ${ }^{34}$ Though the reorganisation of language is occasionally quite extreme, read in the light of the purpose clause it is unlikely that powers of the court contained in s 4 will change.

Section 9 of the Judicature Amendment Act relating to review procedure is re-enacted within cls $428-430 .{ }^{35}$ Section 9 generally dealt with such things as the naming of parties - for example, whether a judge is to be named as a party - and requirements of statements of claim and defence. ${ }^{36}$ Much of it is simply written in modern drafting language. The most notable change is the omission of $s 9(2)$, which provided a statement of claim should state the factual basis of the claim, the grounds of relief and relief sought. Because the High Court Rules already require this for all civil and interlocutory applications, omission of s $9(2)$ is likely unproblematic and without meaningful consequence. ${ }^{37}$

Other changes in statutory language are similarly vivid but equally likely to be toothless. By way of illustrative example, cl 427(1) re-enacts the substance of s 3A of the Judicature Amendment Act as it relates to the High Court's (in)ability to review the Employment Court through judicial review under the statutory process. The obvious addition of specific sections in the Employment Relations Act 2000 into cl 427(2) of the Bill is for the worthwhile avoidance of doubt, yet seemingly redundant given the operation of cl 427(1). Much of the obvious differences in language are in this vein.

\section{Rights of Appeal Curtailed?}

There is, naturally, a caveat. Not every change made is harmless. The purpose clause is not allinclusive; in fact, on closer inspection it appears to be something more like a sieve. It only covers "reorganisation in this Part of those provisions and the changes made to their style and language". ${ }^{38}$ It does not cover any other change arising from other parts of the Bill, whether deliberate or accidental. Accordingly, it seems there will be an amendment to appeal rights, of uncertain extent and perhaps unintentionally, in direct contravention of the purpose clause. ${ }^{39}$ Clause 440 provides:

34 Judicature Modernisation Bill 2013 (178-2), cl 438; and compare Judicature Amendment Act 1972, s 4(3)(4).

35 Judicature Amendment Act 1972, s 9; and compare Judicature Modernisation Bill 2013 (178-2), cls 428-430.

36 Judicature Amendment Act 1972, s 9.

37 High Court Rules, rr 4.1 and 5.26-5.27; and Law Commission, above n 10, at [2.35].

38 Judicature Modernisation Bill 2013 (178-2), cl 423(1).

39 New Zealand Bar Association "Submission to the Justice and Electoral Committee on the Judicature Modernisation Bill 2013" at [113]-[117]. 


\section{Appeals}

(1) Any party who is dissatisfied with any interlocutory or final order made in respect of an application may appeal to the Court of Appeal in accordance with section 57 of the Judicature Modernisation Act 2013.

By including a reference to $\mathrm{cl} 57$, cl 440 of the Bill actually mirrors the Judicature Amendment Act's language. ${ }^{40}$ Any reform arises from changes in $\mathrm{cl} 57$ in pt one of the Bill. Ministry of Justice officials advised the Committee that, as the change arises from a change outside of pt three, there is no clash with the protections afforded by $\mathrm{cl} 423 .{ }^{41}$

At introduction, cl 57(3) provided that the Court of Appeal would have no jurisdiction to hear appeals against interlocutory orders of the High Court in respect of any civil proceeding such as judicial review, unless leave was first granted. Section 66 of the Judicature Act, which cl 57(3) replaces, does not impose a requirement to seek leave before an appeal of interlocutory orders. This inconsistency has been patched at the select committee stage; the relevant part of $\mathrm{cl} 57$ now reads:

57 Jurisdiction

(2A) No appeal, except an appeal under subsection (3), lies from any order or decision of the High Court made on an interlocutory application in respect of any civil proceeding unless leave to appeal to the Court of Appeal is given by the High Court on application within 20 working days after the date of that order or decision or within any further time that the High Court may allow.

(3) Any party to any proceedings may appeal without leave to the Court of Appeal against any order or decision of the High Court-

(a) striking out or dismissing the whole or part of a proceeding, claim, or defence; or

(b) granting summary judgment.

The new cl 57 makes changes in the substantive law of judicial review procedure, despite being amended to account for interlocutory appeals where orders would strike out, dismiss or grant summary judgment in respect of a claim. ${ }^{42}$ Given that judicial review tends to be a quick process ordinarily, the exceptions under $\mathrm{cl}$ 57(3) may have limited effect. Where there is a live issue that needs resolution, an injunction to maintain the position of the parties will not be able to be appealed. Depending on time frames involved, this may have the effect of practically determining the core of a complaint.

40 See Judicature Amendment Act 1972, s 11; compare Judicature Modernisation Bill 2013 (178-2), cl 440.

41 Report of the Ministry of Justice to the Justice and Electoral Committee (April 2014) at [77]-[78].

42 Judicature Modernisation Bill 2013 (178-2), cl 57(3). 
Such changes to appeal rights ought to be avoided. ${ }^{43}$ Nonetheless, this is a substantive change to judicial review procedure.

Whilst the Ministry of Justice was formally correct to identify that this was not a change contemplated by pt three of the Bill, their assurances are less than comforting. The object of the Bill as it relates to judicial review was to avoid substantive reform of any kind. This is substantive reform. Therefore, the object of the Bill has been demonstrably compromised. Additionally, side-stepping consequential reform by saying it is the result of a reference to a reformed provision in the proposed Senior Courts Bill does not inspire full confidence that the entire Judicature Modernisation Bill has been vetted properly to ensure minimal substantive reform will occur. The exact sources of any changes are not relevant, because the public has been assured that there is no material change in substance. The ordinary observer, even a technically skilled one, does not have the resources to confidently second-guess such claims. It is important that their faith is not abused.

Nonetheless, other than $\mathrm{cl} 57$, there is no likely legal change to judicial review processes and powers. I have surveyed here only some of the more obvious changes in statutory language for reasons of space, but the pattern in these changes is clear. The law of judicial review procedure remains substantively the same as it was under the Judicature Amendment Act. The exception is cl 57, the effect of which is uncertain. To the extent the statutory language is distinct it is highly likely to be caught within the expansive purpose clause, preventing change in the law. Although I have shown the purpose clause to be defective, the courts will be unlikely to willingly curtail judicial review. That judicial attitude will have to be enough.

\section{PROPER REFORM PROCESS}

Saying the Judicature Modernisation Bill has more or less succeeded in a modest project of nonsubstantive, or purely visual, reform should not be construed as an endorsement of the attempt. I now turn to the process by which the Bill has moved through the legislature. Although Parliament can in theory make any law it pleases, not all processes are created equal.

The ten indicia identified by Geiringer, Higbee and McLeay provide a good basis for appropriate reform process. $^{44}$ These were: public and open pre-legislative policy processes; adequate opportunities for scrutiny; adequate means of public participation; transparency of process; high quality drafting; caution, when legislating for the basics; preferring stable processes ordinarily; legislating in ways that foster respect for Parliament; allowing the government to implement its policy program; and finally that urgency should be available when genuinely necessary. The ten indicia are more widely applicable than the use of urgency that the authors confined themselves to. They can be

43 Supreme Court, Court of Appeal and High Court "Submission to the Justice and Electoral Committee on the Judicature Modernisation Bill 2013" at [27]-[28].

44 See generally Claudia Geiringer, Polly Higbee and Elizabeth McLeay What's the Hurry? Urgency in the New Zealand Legislative Process 1987-2010 (Victoria University Press, Wellington, 2011). 
fairly extended to include the legislative process in general in any open, free and democratic society such as New Zealand. For present purposes, scrutiny is probably the most important paradigm they refer to. I will focus on scrutiny because it is closely connected with quality drafting and because both together demonstrate appropriate levels of caution. They are all obviously interrelated.

Under that framework the process used to reform pt three of the Judicature Modernisation Bill is deficient for a Bill of such constitutional significance in at least two ways. First, the ideas of nonsubstantive reform and over-reliance on legislative intentions reduce the probability of clear and reliable reform, undermining legislative caution and stable processes. Secondly, as an omnibus Bill the possibility for real scrutiny of the Bill's contents was worryingly inadequate. A lack of parliamentary examination undermined the criteria of transparency and scrutiny. Additionally, the attempt at so-called non-substantive reform is usually a waste of an opportunity to address already identified proposals for reform. These together suggest that Parliament should tread carefully when reforming or adopting constitutional basics in general and judicial review in particular. Judicial review is far too important to get wrong.

\section{A Value of Good Scrutiny in Legislative Process}

For legislation, "[q]uality can be an elusive idea but it does not, like beauty, lie in the eye of the beholder". ${ }^{45}$ It is important to distinguish good or desirable law from effective law in order to emphasise that scrutiny is more about the latter. Effective reform processes will maximise the probability of producing effective law. By contrast, there will be a degree of agnosticism about whether the results of a reform are worthwhile or desirable. That is for legislators to judge and not the legal process itself.

The Judicature Modernisation Bill, as it relates to judicial review at least, is an example of mixed results in the reform process. Although it had reasonable pre-legislative scrutiny - largely defining the parameters of the current reform - this was never second-guessed by Members of Parliament. That politicians should occasionally trust the experts is proper. The issue is rather more that there was no opportunity for the question of trust to arise, because the process of the Judicature Modernisation Bill as an omnibus bill radically limited parliamentary consideration.

Examination of legislation is a crucial part of any legislative process. It has essentially two main purposes. First, scrutiny is essential to the public reform of the law and enhances its legitimacy as law. Adversely, an obvious lack of scrutiny undermines the public's trust in the law and the institution of Parliament generally. ${ }^{46}$ Whilst important in its own right, public confidence in legislation is not strictly the subject of this article. But the second reason scrutiny is important is more relevant; a good

45 Palmer, above $\mathrm{n} 1$, at 3.

46 Geiringer, Higbee and McLeay, above n 44, at 2-3. 
legislative process is one of the most obvious ways to rectify defects in legislative drafting. Since none can second-guess Parliament's enacted law the law must be adequate before it is passed. ${ }^{47}$

Sufficient analysis before and during the legislative process will lead to more technically effective enactments. Public analysis rectifies defects that one person's poor vision can hide. The observable nature of a suitably scrutinised procedure encourages legal actors to provide reasoning for their actions and fixes the debate closely to the purpose of the attempted reform. Parliamentary debate done well reduces indifference to a law, requiring the Members of Parliament to pick one side based on the evidence available. Although this can lead to hasty decisions, it nonetheless trends towards more consideration of a proposed law. Scrutiny enhances the public transparency of reform, enabling critique and warning, and in doing so inhibits the possibility for indifference to result in arbitrary or technically deficient legislative enactments. With more consideration, higher quality law should result.

That said, there is a degree of political incentive on the part of the executive to avoid scrutiny in Parliament. ${ }^{48}$ The extent to which the adoption of mixed member proportional (MMP) elections has ameliorated this is open to debate. Because the executive still largely controls the legislative agenda this has the de facto effect of partially reducing legislative functions to the executive - that is, to Cabinet Ministers in their role as Members of Parliament. In that perhaps limited sense, some laws that Parliament passes may not be, realistically, thought of as Parliament's law at all. ${ }^{49}$ In such cases, the role of the House is abridged as endorsement and legitimisation, a "rubber stamp" of the government policy process. ${ }^{50}$ In my view, the size of the Judicature Modernisation Bill makes it one such bill. Generally, that the executive has political incentives to subsume and interfere with parliamentary scrutiny but is less able to do so consistently means that it is hard to assign blame for inadequate scrutiny to either branch of government. But it must be asked to what extent Parliament really has a role in making the law it passes. ${ }^{51}$ This is why scrutiny is so important during the prelegislative process.

\section{B Considering the Judicature Modernisation Bill's Process}

A brief review of Hansard suggests that the process of reforming judicial review by an omnibus Bill has, so far, been superficial on the part of Members of Parliament. The Judicature Modernisation

47 At 18 .

48 Jo Dinsdale "Law making under MMP: the legislative process and the new standing orders" (LLM Research Paper, Victoria University of Wellington, 1996) at 62.

49 At 62.

50 Keith Jackson The Dilemma of Parliament (Allen and Unwin, Wellington, 1987) at 38, as cited in Dinsdale, above $\mathrm{n} 48$, at 10

51 Palmer, above n 1, at 21. 
Bill is yet to go to the Committee of the Whole House and languishes on the Order Paper; it has not been fully debated. In the first and second readings, judicial review was mentioned a total of seven times. ${ }^{52}$ Only two could be fairly described as substantive mentions, meaning that the comment went beyond pointing out that $\mathrm{pt}$ three of the Bill relates to judicial review. An Opposition Member made the point in the second reading that unrepresented litigants take up a substantial amount of judicial time in review proceedings by not knowing their rights. ${ }^{53}$ A Government Member made the point shortly afterwards that judicial review is sometimes used by applicants to widen the realm of legal issues the court can consider in a case. ${ }^{54}$ Whilst neither point is without value, they are hardly incisive commentary.

Against this sparse consideration, it is decidedly concerning to see what was genuinely debated. Members contested the Bill's definite size - that is, the number of pages - no less than three separate times. The size of the Bill was mentioned nine times in the first reading and 18 times in the second. Some Members did not even address the subject matter of the Bill: one Member talked about ultrafast broadband instead. ${ }^{55}$ There were jibes at the age of other Members. Two Members admitted to not reading the full text of the Bill. ${ }^{56}$ While Members are not required to read every bill they pass, something more is hoped for from Parliament when it passes constitutional legislation. Judicial review was simply not salient in the parliamentary awareness. In light of this, can we really "have faith in the group mind"? ${ }^{57}$

Other matters were the subject of parliamentary time in the readings and at select committee instead. Twenty-five written submissions were received by the Committee. ${ }^{58}$ Specialist submissions of various judicial benches and commercial law firms accounted for 11 submissions. ${ }^{59}$ These generally dealt with the specific matters affecting a particular court in question or were general commentary, part by part, on the Bill. Of the remaining 14, seven dealt with the rights of victims of

52 See generally (5 December 2013) 695 NZPD 15299-15314 (first reading); and (18 February 2015) 703 NZPD 1725-1749 (second reading).

53 (18 February 2015) 703 NZPD 1733 per Hon David Parker MP.

54 At 1745 per David Bennett MP.

55 (5 December 2013) 695 NZPD 15313-15314 per Clare Curran MP.

56 (18 February 2015) 703 NZPD 1729 per Jacqui Dean MP, and at 1733 per Jonathan Naylor MP.

57 At 1742 per Kennedy Graham MP.

58 Report of the Ministry of Justice to the Justice and Electoral Committee, above n 41, at [3].

59 All submissions can be found at House of Representatives "Judicature Modernisation Bill" (18 February 2015) <www.parliament.nz>. The 11 specialist submissions include those from the New Zealand Law Society, the New Zealand Bar Association, Buddle Findlay, Bell Gully, Arbitrators' and Mediators' Institute of New Zealand, the Royal Federation of New Zealand Justices Association and representatives of the Judges of the Environment Court, Employment Court, Māori Land Court, District Courts and the senior Courts. 
crime. ${ }^{60}$ Four of that seven clearly wanted more punitive treatment of offenders or greater judicial accountability to prevent a perceived judicial coddling of criminals - a topic, it must be noted, relatively unrelated to the structure and powers of courts. Two of the 14 dealt with the award of damages for copyright violation. ${ }^{61}$ One related to what seems to be an undefined personal grievance. ${ }^{62}$ The remaining four dealt with genuine constitutional matters, such as the omission of s 3 of the Supreme Court Act $2003 .{ }^{63}$ Only one submission dealt with judicial review primarily. ${ }^{64}$ It would be interesting to see what effect the omnibus nature of the Bill has had on these patterns and whether more submissions on judicial review would have been made on a stand-alone Bill. My suspicion is that there would be.

Amendments made at select committee were presented without comment and judicial review went (substantively) unmentioned in the Committee's report. ${ }^{65}$ Given lack of coverage in the submissions, that is unsurprising. As the mind of the Committee was generally directed elsewhere, the process of the Judicature Modernisation Bill as an omnibus bill is questionable. But it is too harsh to conclude there was no scrutiny. For example, the scarce submissions on judicial review eventuated a change to the definition of "person" in pt three to bring it more in line with the Judicature Amendment Act 1977's definition. ${ }^{66}$ The problems with appeals have been attempted to be solved, so those changes to judicial review are at least deliberate. Besides this, there were a number of technical changes that Parliamentary Counsel determined were necessary.

Such generality of submissions is insufficient overall when legislating for judicial review. The process the Bill has gone through seems automatic and superficial, focussing instead on headline political issues like criminal sentencing and online courts. That this criticism is not new is additionally

60 See the submissions of Ruth Money, Rethinking Crime and Punishment, Red Raincoat Trust, Harry Young, Dirk Anderson, Brendon Cullen and the Sensible Sentencing Trust.

61 See the submissions of Recorded Music New Zealand and Copyright Licensing New Zealand.

62 See the submission of Milton Pedley.

63 See the submissions of Jack Hodder QC, Human Rights Commission, Richard Cornes and Dean Knight.

64 See the submission of Dean Knight.

65 Judicature Modernisation Bill (178-2) (select committee report).

66 Drafting notes by Parliamentary Counsel Office on part three of the Judicature Modernisation Bill (version 19.1, 15 May 2014). See also Judicature Amendment Act 1977, s 10. 
discouraging. ${ }^{67}$ There is limited basis for concluding that scrutiny of the Bill's effects on judicial review was adequate. ${ }^{68}$

\section{Improving Reform Processes}

The nature of the Judicature Modernisation Bill and its attempted non-reform appear to be intended to be a temporary measure designed to prolong the status quo until a proper review of judicial review is undertaken. ${ }^{69}$ This is not an excuse for ineffective scrutinising of the Bill. Fortunately, improving reform procedures is a rather straightforward affair.

In general, constitutional reformers should avoid omnibus bills. Omnibus bills have much the same issues as bills under urgency in that they stifle time to debate, when time is needed to digest all the ramifications of a proposed bill. ${ }^{70}$ For example, one Member remarked when he took a split call that he had 50 seconds for every 200 pages of the Bill. ${ }^{71}$ A hurried and opaque legislative procedure inhibits scrutiny, ${ }^{72}$ which is precisely why omnibus bills are generally reserved for non-contentious amendments. ${ }^{73}$ The problem is that constitutional issues are relatively contentious by virtue of their fundamental nature. That is, simple constitutional changes still reflect complex and contestable value judgements. When reform is done by omnibus bill, even a well-drafted constitutional bill will become lost in the other parts of the bill, as has happened here with the Judicature Modernisation Bill. Standalone bills are better because they improve the transparency and publicness of a bill. They invite better examination.

Good scrutiny will never overcome the problems of ill-considered legislation. That is, New Zealand has a problem with over-legislating. ${ }^{74} \mathrm{We}$ tend to legislate in large statutes; yet we will tinker without principles around the edges when we do not like the results. ${ }^{75} \mathrm{We}$ also tend to legislate for

67 Palmer, above n 1, at 20-21, especially the criticisms relating to the Justice and Electoral Committee's report on the Judicature Modernisation Bill.

68 Giving reasons in Parliamentary Counsel Office drafting notes would be of immeasurable help to people undertaking projects similar to mine. It is hard to infer intention of the drafters without them.

69 Law Commission, above n 10, at [2.4]-[2.19].

70 Geiringer, Higbee and McLeay, above n 44, at 142.

71 (18 February 2015) 703 NZPD 1743 per Hon Phil Goff MP.

72 Philip A Joseph Constitutional and Administrative Law in New Zealand (4th ed, Brookers, Wellington, 2014) at [11.7.0]-[11.7.2]. See also John Burrows and Philip A Joseph "Parliamentary Law Making" [1990] NZLJ 306

73 Geoffrey Palmer New Zealand's Constitution in Crisis: Reforming Our Political System (John McIndoe, Dunedin, 1992) at 121, as cited in Dinsdale, above n 48, at 19.

74 Palmer, above n 1, at 5.

75 At 3-4. 
things that do not require legislation at all. ${ }^{76}$ These habits contribute significantly to the parliamentary workload - the "legislative bottle-neck" - incentivising cursory analysis in order to facilitate the appearance of getting things done. ${ }^{77}$ A degree of caution about codification and statutory construction is necessary, so as to not make regrettable mistakes that will need repair later. It is also better not to legislate at all if it is not needed. Getting it right will free up parliamentary time for more important and relevant matters, and provide more resources to use on legislative scrutiny.

Certainly, no reform is likely to be fully scrutinised to the utmost extent. Effective scrutiny is more of an ideal towards which we aim. However, that success is an ideal that does not justify continual failure; reform can be done better if done in public and for the right reasons.

\section{PARLIAMENT SHOULD TREAD CAREFULLY WHEN USING LEGISLATIVE POWER}

Need for adequate scrutiny is in the foreground of any structural reform of the New Zealand state. Analysis on legislative process above was defined by the simple idea that the boundaries of the public sphere and public power should be set by a clear and accessible process. The constitution is a public covenant that should not be altered inadvertently, capriciously or in secret. ${ }^{78}$ Similarly, to aid quality reform, Parliament should show deference to the courts on such matters as judicial review and judicial independence. This is not a challenge to the claimed full powers of Parliament to make law, but an argument for additional respect or deference to matters relating to the common law powers of the courts. It is animated by a desire to secure independent administration of the law of judicial review and the spirit of comity.

The fundamental basis of the power of Parliament is found in the principles of democracy and the rule of law. Many theories of the rule of law explicitly hold that, ideally, the law governs all equally and independently of their role in society. ${ }^{79}$ Similarly, democracy is often argued to decentralise political power. ${ }^{80}$ Each of these separately requires that the state is subject to law at the suit of a private citizen, which is only achievable when a judge can rule against the government "without fear

76 For a well-publicised recent example, see the Sale and Supply of Alcohol (Rugby World Cup 2015 Extended Trading Hours) Amendment Act 2015.

77 Palmer, above n 1, at 6.

78 See Joseph Raz The Authority of Law: Essays on Law and Morality (Oxford University Press, Oxford, 1979) at ch 11 , where he discusses the instrumental value of law.

79 See for example Palmer "New Zealand Constitutional Culture", above n 3, at 587; Brian Tamanaha On the Rule of Law: History, Politics, Theory (Cambridge University Press, Cambridge, 2004) at 114; and Lord Bingham "The Rule of Law" (2007) 66 CLJ 67 at 69 and 73-75.

80 See for example Andreas Kalyvas "Popular Sovereignty, Democracy, and the Constituent Power" (2005) 12 Constellations 223 at 238 . 
or favour". ${ }^{81}$ Making application of the law independent from its administration or creation is the very first condition of a system that functionally follows either principle. ${ }^{82}$ Independence of the law is instrumentally valuable, in order to limit the arbitrary usage of state power.

Ministers, and the bodies accountable to them, take decisions according to the law as defined and interpreted by the courts. Accordingly, courts have a role as scrutineer of government power. ${ }^{83}$ In a political climate still dedicated to the concept of two main parties, I am sceptical that the MMP electoral system has properly limited executive influence of the House. As Ministers hold office by virtue of collectively having confidence of the House, ${ }^{84}$ and control the legislative agenda, the executive retains much of the substantial power over law that it possessed under the old system. ${ }^{85}$ Reduced separation is not conducive to good process; as one of the mechanisms to define due process, judicial review is an important safeguard in the New Zealand context.

Still, there is no need to insist on the full tripartite separation of powers that is endured by certain foreign states, provided that the courts remain suitably independent. As Montesquieu puts it, there is no liberty "if the power of judging is not separate from legislative power and from executive power". 86 Yet even a brief look at modern Westminster democracies indicates that a politically responsive legislature may be fused with the executive with only minor problems. This is merely Bagehot's efficient secret in action. ${ }^{87}$ It goes too far to describe separation of powers as a "constitutional myth" in New Zealand. ${ }^{88}$

The sometimes underappreciated consequence of fusion, however, is to radicalise the importance of judicial independence. It is improper that a fused legislature-executive takes too much interest in regulating the judiciary's inner workings. Since not much thought is given to separation of the branches of government, legislative-executive caution becomes in a certain respect a democratic imperative. This is necessary to protect against centralised power.

It also must be questioned what role Parliament actually can play in the law of judicial review. Besides the instrumental argument for caution advanced above, there is also a question over the actual

81 Oaths and Declarations Act 1957, s 18 (the judicial oath).

82 See generally Palmer "Assessing the Strength of the Rule of Law in New Zealand", above n 3, at 6-7.

83 Richard Mulgan Politics in New Zealand (3rd ed, Auckland University Press, Auckland, 2004) at 70.

84 Cabinet Office Cabinet Manual 2008 at [6.37]-[6.42].

85 Joseph, above n 72, at [11.6.3].

86 Montesquieu "The Spirit of the Laws" as cited in Arend Lijphart (ed) Parliamentary Versus Presidential Government (Oxford University Press, Oxford, 1992) at 48-49.

87 Paul Smith (ed) Bagehot: The English Constitution (Cambridge University Press, New York, 2001) at 8-9.

88 Mulgan, above n 83, at 69. 
legal legitimacy of parliamentary involvement. It is widely agreed that there is no statute conferring the power of review; even the Judicature Amendment Act is only a process statute. ${ }^{89}$ Without a clear statutory culprit, only limited guidance is given to the courts in determining the proper extent of review. Such historical ambiguity about the source of review powers suggests that a degree of parliamentary co-operation typified through appropriate levels of scrutiny and consultation is desirable, if not obligatory.

Debate between the ultra vires models and common law illegality models of review is unresolved.${ }^{90}$ It is not possible, nor necessary, to undertake a suitably thorough review of the common law illegality and ultra vires models of review in this article. Nonetheless, such debate is not merely academic. The strong corollary of an ultra vires interpretation is that the proper role of review, besides to prevent material errors of law, is to ensure that discretion of administrators is exercised in accordance with Parliament's manifest or presumed intention. Yet upholding Parliament's intention is not the same as upholding fundamental principles like the rule of law. Given the instrumental objection above, that Parliament is controlled by the executive, the ultra vires model has ramifications for potential efficacy of review as a check on executive power.

If there is no statute creating judicial review, then this suggests that the courts did so through the ordinary process of precedent, regardless of their justifications for doing so. ${ }^{91}$ Further, in the context of imperfect legislative scrutiny it is dangerous to read too much into what Parliament intends by its (non-)addressing of an issue. Not only that, intentions that could be inferred are given life by judicial officers. ${ }^{92}$ Should it be shown that review is a common law development, as I believe it to be, then the argument for caution is strengthened somewhat. Attitudes of comity would suggest that Parliament should not second-guess courts' decisions to use review as a vehicle for the judicial function of upholding the rule of law. Thus, a common law review power would speak against parliamentary regulation. Accordingly, the origins of review affect the appropriateness of its reform by statute.

Judicial review's status as part of the inherent jurisdiction of the courts is not necessarily enough to avoid the reply that Parliament can make any law it wishes, including to exclude review. In that sense there is little legal difference between modified ultra vires review and weak illegality review; judicial review can still be the plaything of Parliament. But it leaves open the possibility of strong illegality review endorsed by Allan and later consequential challenges against legislative

89 Law Commission, above n 10, at [2.2].

90 For discussion of the origins of review, see generally AW Bradley and KD Ewing Constitutional and Administrative Law (15th ed, Pearson, Harlow, 2011) at 670-671; Mark Elliott "The Ultra Vires Doctrine in a Constitutional Setting: Still the Central Principle of Administrative Law" (1999) 58 CLJ 129; Paul Craig "Ultra Vires and the Foundations of Judicial Review" (1998) 57 CLJ 63; and Allan, above n 6, at 207-215.

91 Taylor, above n 7, at 3; and Craig, above n 90, at 79-86.

92 Allan, above n 6, at 207. 
sovereignty. ${ }^{93}$ Although I do not necessarily endorse orthodox conceptions of parliamentary sovereignty, this article is not the time to challenge them either.

The major advantage of parliamentary caution is that it makes clearer the constitutional tightrope Parliament walks when it legislates for the basics. As a political rather than legal settlement, it avoids problematic power transfers to the courts - but at the cost of not necessarily resolving the underlying theoretical problem that Parliament is sovereign. ${ }^{94}$ Increased scrutiny of the tensions between legislature and judiciary may be enough to prevent an abuse of legislative power; equally, however, it may simply mean we see the abuses coming more easily. Nothing about a convention of deference ensures deference will occur. That reality incidentally raises the general question of whether the New Zealand constitutional order is capable of properly securing judicial review against executive interference. But for now, it suffices to say that judges may not take parliamentary intervention well in all future cases. ${ }^{95}$

Constitutional uncertainty is the necessary cost of an attempted practical fix of a problem few in the ordinary public have identified. New Zealand's constitutional culture tends to support leaving the decisions about judicial review to Parliament. ${ }^{96}$ This is a political preference about constitutions that deserves recognition. That it makes some uncomfortable in the light of constitutional unawareness in New Zealand cannot rob that preference of legitimacy. Geiringer, Higbee and McLeay's ninth principle, that government has power to create and implement policy, is based on an important insight about the different bases of power the judiciary and Parliament have. ${ }^{97}$ The judiciary's power comes from fundamental legal standards and values; whereas Parliament is thought to take its power from the desires of the people. ${ }^{98}$ These different legitimating dynamics deserve respect.

\section{WHAT GOOD REFORM MAY LOOK LIKE}

It would be remiss to criticise the Judicature Modernisation Bill's processes and substance without some sort of analysis as to potential legislative alternatives. This article provides one potential solution, but it means a political willingness to cede power to legislate for judicial review. I argue that Parliament should provide that judicial review exists and leave the common law to its own devices.

93 At 209. See also Sir Robin Cooke "Fundamentals" [1988] NZLJ 158 at 163-165. These debates in New Zealand have more potency given issues of Māori rights and sovereignty.

94 Jeremy Waldron "Judicial Review and Judicial Supremacy" (Francisco Lucas Pires Distinguished Lecture, Catholic University of Portugal, Lisbon, 2 October 2014).

95 See by way of example Cooke, above n 93; Taylor v New Zealand Poultry Board [1984] 1 NZLR 394 (CA) at 398 per Cooke J; and Elias, above n 2.

96 Palmer "New Zealand Constitutional Culture", above n 3, at 582-589.

97 Geiringer, Higbee and McLeay, above n 44, at 19.

98 Palmer "New Zealand Constitutional Culture", above n 3, at 585-586. 
A more broad-based constitutional reform would require sufficiently widespread support for that to be a viable proposal and in the apparent absence of such support this article does not consider that possibility. Thus, I have so far established the importance of judicial review and why Parliament should therefore be careful not to break it. As one of the pre-eminent tools in the public law space, it remains a multifaceted and useful - if sporadic - tool used to protect administrative process from governmental overreach. ${ }^{99}$ Frequently, it is a safeguard against simple executive mistake.

More importantly, the common law nature of review is politically significant. It is in line with some more modern notions of sovereignty that diffuse power amongst the different organs of government. ${ }^{100}$ Nor does it limit the possibility of constituent power in the way the ultra vires model, by conforming to traditional ideals of sovereignty-as-command, does. ${ }^{101}$ But, more practically, widespread acknowledgment of the court's role in creating review demands greater respect for the opinions of court officials; there is a greater moral mandate for them to defend review from parliamentary interference. Such encouragement of co-operative behaviour from Parliament when it legislates for review promotes reciprocity and a spirit of comity. That is perhaps the real value of common law conceptions of review: it encourages Parliament to share its power and to use that power more cautiously.

It is clear that to some degree the Judicature Modernisation Bill neglected needed reforms of judicial review procedure. For instance, jurisdictional problems in case law on the Judicature Amendment Act remain unresolved. ${ }^{102}$ The courts sometimes neglect to analyse the suitability of applying public law norms. It is not the law that the hypothetical perfectly private incorporated society is subject to review for the mere misuse of a power under its instruments of incorporation. What constitutes a reviewable decision in the courts is conceptually difficult, but it is clear that publicness is essential; ${ }^{103}$ and reform of the statutory procedure may be necessary to make that clear. Even if the exact distinction is ill-defined, that the law should not impose public law norms on private activity is uncontroversial.

99 Crown Law Office The Judge Over Your Shoulder: A Guide to Judicial Review of Administrative Decisions (Crown Law Office, Wellington, 2005) at [7]

100 Moana Jackson "Where Does Sovereignty Lie?" in Colin James (ed) Building the Constitution (Institute of Policy Studies, Wellington, 2000) 196 at 196-197; and for a more historical perspective, see Paul McHugh "Sovereignty This Century - Maori and the Common Law Constitution" (2000) 31 VUWLR 187.

101 Kalyvas, above n 80, at 229-230.

102 See generally Knight, above n 26.

103 Hopper v North Shore Aero Club Inc [2007] NZAR 354 (CA); and see Knight, above n 26, at 112-113 for comparison with Stratford Racing Club Inc v Adlam [2008] NZCA 92, [2008] NZAR 329. 
Similarly, the question of mandatory orders against the Crown remains undealt with. ${ }^{104}$ Courts still only have the power to declare what the Crown ought to do as a result of review proceedings rather than to direct it. ${ }^{105}$ Perhaps this ought to be changed to enhance the functionality of the rule of law. It is not necessarily clear why the Crown should avoid liability for poor decisions where there is no public policy justification, or how Crown immunity is consistent with the rule of law. ${ }^{106}$

Specific remedies to these issues may be achieved through statutory reform, whether of the qualification of what constitutes a "statutory power" or to recreate an alternative tribunal process for grievances arising out of non-public decisions. The potential content of such reforms is not the focus of this article. Rather, a status-quo re-enactment has done nothing to resolve these previously identified issues. That insight is in itself not new. ${ }^{107}$

Statutory solutions are generally unsuitable for judicial review. Statutory drafting, like chess, "requires participants, each time they need to make a decision, to consider many relevant factors. Thus, in both activities every move has many implications." 108 Given that judicial review is a legal tool of some constitutional delicacy, it remains ever important to implement certain and stable reform. The statutory remedies required to reform judicial review would mostly tend to the technical and the specific, and are demonstrably unlikely to receive the scrutiny they deserve. At least, they are likely to receive a similarly cursory consideration to the Judicature Modernisation Bill. Accordingly, there is a chance that any reform would be in error. Even if successful, it would be to fix the development of the judicial review power in a way that was possibly undesirable.

Nor is it safe to argue that any problem for judicial review stemming from legislative action may be resolved by careful statutory interpretation. ${ }^{109}$ That relies on suitable respect for courts enabling the weathering of any controversy. Instead, our cultural respect for the rule of law is rather weak. ${ }^{110}$ Thus, where statute is ordinarily a "continent with the ocean of common law", for judicial review statute is better to be an atoll. ${ }^{111}$

104 Law Commission Mandatory Orders against the Crown and Tidying Judicial Review (NZLC SP10, 2001).

105 Judicature Modernisation Bill 2013 (178-2), cl 435(3).

106 Law Commission, above n 104, at [16]-[27].

107 Knight, above n 26, at 123.

108 Jack Stark "The Proper Degree of Generality for Statutes" (2004) 25 Stat LR 77 at 77.

109 Allan, above n 6, at 210-211.

110 Palmer "New Zealand Constitutional Culture", above n 3, at 589.

111 Legislation Advisory Committee Legislation Advisory Committee Guidelines: Guidelines on Process and Content of Legislation (Ministry of Justice, May 2001) at 43. 
It is worth pursuing an elegant alternative: repeal the procedural elements of the Judicature Amendment Act and Judicature Modernisation Bill, and replace them with a provision that simply recognises judicial review as existing. The Law Commission appeared to be considering this possibility in $2001 .^{112}$ This solution appeals because the development of judicial review procedure is not held hostage by the legislature. Furthermore, it is agnostic about what constitutes good review, leaving such inquiries to the court on a fact-sensitive basis. Because it leaves the development of review outside the power of the legislature, the problems created for the rule of law by an inadequate separation of powers are reduced. For this rather persuasive reason alone, the courts should be the dominant actors in reform of judicial review.

\section{CONCLUSION}

This article arose out of an enduring desire for quality law reform. I am reassured not to see the errors in the Judicature Modernisation Bill that I initially feared. Rather, the Bill is by-and-large a technically competent re-enactment of the Judicature Act 1908, including as it relates to judicial review. Curtailment of appeal rights is a blot on the record of attempts at non-substantive reform, but in itself is a policy decision the Government is entitled to make. Therefore, on the whole, the Bill is reasonable. But it is also a Bill passed under dangerously low levels of parliamentary scrutiny. As I have shown, assurances that there would be no substantive changes whatever are inaccurate. Because of the opaque nature of that lapse, it was not immediately obvious what was to be changed for judicial review - not to the wider public, at any rate. This is a shame, because these changes needed to be seen.

I have discussed the Bill as an example of an attempt at non-substantive reform of judicial review procedure. Although it is likely to be successful in this unambitious target, such an attempt was in the first place misguided due to the incomplete protection afforded by a purpose clause. In making that critique I advanced an argument for parliamentary caution or deference when legislating for constitutional fundamentals, in spite of its legal ability to make any law it pleases. A necessary part of such caution is that bills go through proper and thorough scrutiny prior to receiving the royal assent. For that reason, omnibus bills are to be avoided when passing constitutional legislation.

Similarly, judicial review maintains its important position in public law because it is one of the most prominent means for citizens to enforce their procedural rights against the executive. It is not appropriate that Parliament retains the political mandate to legislate away the basis of review proceedings or otherwise restrict their availability carte blanche. There is a palpable tension between the rule of law and parliamentary sovereignty that must abate. It is unseemly for parliamentarians to ask us to rely on their conscience for such fundamentals.

112 At 44; the Law Commission review referred to appears to be the one cited above at $\mathrm{n} 104$. 
It is, in the end, a debate about who should have the final word on judicial review. When legislating for the constitutional basics, Members of Parliament should do so for the right reasons and in the eyes of the public. There needs to be a certain regard for the principle of comity and the obligations it imposes on all branches of government to respect each other. In particular, since the executive largely controls the legislative agenda in practice, the legislative agenda should not extend to judicial review of executive action. Good legislative process will sometimes necessitate deference. To err too much may earn judicial animosity. If the thin veil between law and politics is pierced, the rule of law will likely be the first victim of a breakdown in relations. This is an outcome surely all of us wish to avoid. 
